Not to be cited without permission

Paper prepared for the Korea Development Institute 20th Anniversary

Symposium on "Economic Growth of Developing Countries: 1940s-1980s," Seoul, July $1-3,1991$.

\title{
WHY GROWTH RATES DIFFER: \\ THE POLITICAL ECONOIY OF SOCIAL CAPABILITY \\ IN 21 DEVELOPING COUNTRIES
}

by

Deepak Lal*
UCLA Dept. of Economics
Working Paper \#642
October 1991

Address for correspondence:

Dept of Economics

University of California, Los Angeles

Los Angeles, CA 90024-1477 USA

*Professor of Political Economy, University College London, and James S. Coleman Professor of Development Studies, UCLA. 
ABSTRACT

This paper first summarizes the evidence on the proximate causes of growth in a sample of 21 developing countries studied as part of a large multi-country comparative study. It briefly examines various endogenous growth models and finds only one .. due to Scott .. to be consistent with the evidence from the 21 country studies. The paper then outlines a $3 \times 2 \times 5$ fold classification of the countries initial resource endowments, organizational structure and polities to draw comparative historical judgments on the deeper determinants of growth. The final part outlines the policy framework which on the basis of the country studies is most likely to foster social capability. 


\section{INTRODUCTION}

The organizers of this symposium have asked participants to consider the role of what they have termed social capability as a determinant of the differing growth performance of developing countries over the last three decades. This term, as I understand it, is meant to cover all those causes of growth which go beyond the proximate ones - - the level of investment and its efficiency -- in explaining differences in growth rates. These include: entrepreneurship, learning by doing, organizational and institutional aspects related to transactions and information costs, as well as the general economic and political framework which determine the relative costs of doing business in different countries, as well as their efficiency of investment, and levels of thrift. A recently completed multicountry comparative study co-directed by the author and Hla Myint for the World Bank, was explicitly designed to provide some answers to a similar set of questions. $^{1}$ It was based on in-depth historical studies of 21 developing countries, which explored the role of (a) initial conditions-resource endowment and economic structures; (b) national political institutions and economic organization and (c) economic policles (including alternative policies which might have been undertaken). In this paper some of the results emerging from the synthesis volume (Lal-Myint (1991)) which provides the comparative analysis of the country studies, are used to answer some of the questions concerning social capability -- what it is, and how it can be fostered.

The paper is in 3 parts. In the first we examine the evidence on the proximate causes of growth in our sample of 21 developing countries. We also briefly look at various endogenous growth models, recently developed 
under the rubric of the "new" growth theory, to see if they can provide the requisite explanations, and find them lacking. In the second part we provide a brief outline of a $3 \times 2 \times 5$-fold classification of our countries initial resource endowments, organizational structures, and polities, which we found useful in making our comparative historical judgments on the deeper determinants of growth. The third part outlines the conclusions on the policy framework which we found best serves to foster social capability.

\section{THE PROXIMATE CAUSES OF GROWTH}

Table 1 shows the per capita income levels and growth rates of per capita GDP in Kravis dollars for the 21 countries in the Lal-Myint study between 1950 and 1985. Fig. I charts the real per capita income figures for 1960 and 1985. The wide divergence in growth performance in the sample is obvious. The major qualitative conclusion emerging from the country studies - - the building blocks of the comparative analysis -. was that relative differences in both the level and efficiency of investment were the proximate causes of the difference in growth performance in our sample. Furthermore the policy regime was crucial in explaining the differences in the efficiency of investment. Outward orientation as well as the absence of policy induced distortions in the working of the price mechanism, were important aspects of the policy regime determining growth performance. Finally, and most important some of the studies (particularly that of Hong Kong) demonstrated the importance of entrepreneurship, and an economic environment which reduces the costs of doing business as important determinants of better growth performance. ${ }^{2}$

Crude statistical representations of some of these conclusions of the analytical economic histories of the countries on which they were based, are provided by cross section, two stage least square regressions (TSLS) we ran 
on the summary data of their economic performance. Table 2 summarizes these regression estimates for (a) GDP growth rates between 1950-85 from the country studies, (b) Kravis dollar growth rates of real GDP between 1960-85, as the dependent variables. Various structural and policy variables (listed in the notes to the Table) were used to form instruments for the two independent endogenous variables, the investment rate and the export growth rate (used as a proxy for the openness of the economy).

The investment rate is invariably positively correlated with the growth rate at a highly significant level, as is the proxy for openness. Alternatives measures for human capital and the share of government spending in GDP, which for instance Barro (1991) found were statistically significant in his cross section regressions of the whole Kravis sample, did not appear to be of any importance in explaining differences in growth rates, in either our country studies or the cross country regressions. The latter which included a composite distortion index developed by Aggarwal (1983) as an independent variable did provide cross section statistical support for the conclusion of the country studies that the relative level of policy induced distortions is an important proximate cause of differences in the efficiency of investment and hence in growth performance.

As is well known, the standard Solow-Swan neoclassical model predicts that in the long run growth is dependent entirely on exogenous factors -the rate of labor-augmenting technical progress and the rate of growth of the quality adjusted labor force. Neither policy, which determines the efficiency of investment, nor preferences, which determine its level, affect the steady state growth rate of GDP. This has troubled theorists. Thus Kaldor (1957) and Arrow (1967) tried to endogenize technical progress, by making it depend on the rate of investment. But their models still only led 
to level rather than growth effects of changes in investment.

After a hiatus of two decades there have been fresh attempts to endogenize growth within the Solow-Swan framework (see in particular Lucas (1988), Romer (1986, 1989)). But they are not persuasive, as their key features - - a particular value of a parameter which yields increasing returns to investment in Romer, and an unexplained externality to human capital in Lucas - - which yield their endogenous growth results seem arbitrary and implausible (see Stern (1991) for a succinct critique). Moreover as Benhabib and Jovanovic (1991) have shown, the empirical evidence cited in Romer (1987) in support of aggregate increasing returns to capital and labor because of an externality associated with capital investment, is not supported by an alternative explanation of the same cross section evidence. They instead argue that, the evidence is consistent with the Solow-Swan model, in which:

the variation in countries' growth rates is consistent with each country having the same constant-returns to scale production function and with a stochastic process for technological change that is the same across different countries but starts from different initial positions.

Moreover they interpret these "technology shocks":

broadly to include shifts in institutional and organizational structures, such as shifts in the corporate, legal or bureaucratic structures, or even in attitudes to work. These elements can greatly enhance or retard the effective use and operation of factors of production.

(p. 102)

They admit that these technology shocks which are their engine of growth are still another "black box". But what they "have shown is that this engine is fuelled primarily by something other than physical capital" (p. 102).

A more promising model from the "new" growth theory stable is that of Murphy-Shleifer-Vishny (1991). This endogenizes growth by assuming that there are increasing returns to ability (talent). "Talented people typically 
organize production by others, so they can spread their ability advantage over a larger scale" ( $p$. 503). The economic environment then determines whether a country's talented people start firms, innovate and foster growth, or become rent seekers aiming to merely redistribute wealth, thereby reducing growth.

This model fits in well with another "endogenous" growth model due to Scott (1989). His model is a direct descendant of what Johnson (1964) called the "generalized capital accumulation" approach deriving from Irving Fisher (1930). This sees capital accumulation broadly defined to include al1 forms of investment which yields a stream of income over time. But:

"investment" in this context must be defined to include such diverse activates as adding to material capital, increasing the health, discipline, skill and education of the human population, moving labor into more productive occupations and locations and applying existing knowledge or discovering and applying new knowledge to increase the efficiency of productive processes. All such activates involve incurring costs, in the form of use of current resources, and investment in them is socially worth while if the rate of return over costs exceeds the general rate of interest, or the capital value of the additional income they yield exceeds the cost of obtaining it. (Johnson (1964) p. 221)

This wider notion of investment as the prime mover of the growth process also makes growth endogenous "and is a potent simplification of the analytical problem of growth, and one which facilitates the discussion of problems of growth policy by emphasizing the relative returns from alternative investments of currently available resources" (ibid.) Scott's endogenous neoclassical equilibrium growth model is the fullest working out of this approach. He makes three departures from the Solow-Swan framework. First, he argues that depreciation is essentially a transfer of income from capitalists to workers in a progressive economy. Were the "appreciation" (in workers incomes) which results, not excluded as it is in conventional accounting, then "net investment for society as a whole is 
(approximately) equal to gross investment as conventionally measured, and not to gross investment minus depreciation" (Scott, op cit., p. 92). ${ }^{3}$

Second, Scott argues that there are no diminishing returns to cumulative gross investment (that is the capital stock measured as the sum of all past gross investments), but there could be diminishing returns to the rate of investment.

Third, he argues there is no need to invoke any independent or exogenous technical progress to explain growth. He argues that:

investment is ... by definition ... the cost of change, and so will cover all activities associated with growth (p. 137) and that

growth due to capital and technical progress are both the result of investment

(p. 330)

in the sense of

the cost, in terms of consumption foregone, of propelling the economy forward instead of leaving it in a stationary state.

He adds

incurring capital expenditure leads to a rearrangement of the things of this world. It does not lead to there being any more of some substance "capital". There is then simply change which is due to investment, and to population growth. (ibid, p. 331)

Scott then provides a detailed empirical analysis of the conformity of the growth experience of the currently developed countries to his model. We carried out a regression analysis similar to Scott's for our sample of 21 countries and found that the estimated equation (using TSLS) (where $g$ - is growth rate of GDP $1950-85$; $s$ - average gross investment rate 1950-85; 8 Lgrowth rate of labor force 1960-85 (due to lack of data we could not use the correct varlable which adjusts for the quality of the labor force)) was: 


$$
\begin{aligned}
g= & 0.71 \mathrm{gL}+0.15 \mathrm{~s} \\
& (1.8 \quad \text { (2.99) } \\
& \text { (t ratios in brackets) }
\end{aligned}
$$

The differences in the efficiency of investment in our sample of counties can be seen from Table 3, which reports the estimated average rate of return (within the Scott framework) for those countries where data on the share of wages .. a crucial variable .. was avallable.

It would seem, therefore, that the relative efficiency of investment, even more than its level, was the crucial proximate determinant of growth rate differences. The policy regime was in turn crucial in explaining these differences in efficiency. This raises the deeper question subsumed in the notion of "social capability", of why countries adopted the policy regimes they did, and why some of them changed these during the 25 years covered in the country studies.

\section{THE $3 \times 2 \times 5$ COMPARATIVE PRAYEWORK}

The role of initial conditions in determining growth outcomes was captured in the synthesis of the country studies by a three-fold classification of the countries into "labor abundant," "land abundant" and "intermediate" using a three factor (land, labor and capital) trade theoretic framework due to Krueger (1977) and Leamer (1984, 1987). The Appendix provides a highly condensed account of the model. It yields a rich menu of alternative efficient paths of development and the implied patterns of changes in the functional distribution of income over time. Fig. 2 depicts the classification of our countries by their factor endowments in 1958 and 1978 in an endowment triangle devised by Leamer (1987).

Second, a two-fold organizational dichotomy was used to qualify the initial adaptations required to realize the potential comparative advantage 
in small scale labor intensive peasant exports and in large scale plantation and mining exports among the "land abundant" and "intermediate" groups of countries (see Myint (1985) for details).

Third, a five-fold classification of the polity was found useful. This distinguished between the objectives of the government and constraints on its activities. On the latter distinction, two basic types of state were distinguished - the autonomous state and the factional state. In the former the State subserves its own ends. The autonomous state classification can be further subdivided by the different objectives of the state. The first is the benevolent state, which is the Platonic Guardian state of public economics. The other is the predatory state, ${ }^{4}$ whose self-seeking can take either the form of the absolutist state seeking to maximize net revenue for the use of the sovereign, or the bureaucratic state concerned with maximizing public employment.

The factional state by contrast subserves the objectives of the groups who are successful in its capture. Two broad types were distinguished .. the oligarchic state and a majoritarian democracy (see Lal (1989) for details). Table 4 shows how our countries were classified to reflect the central tendency of the polity as identified by the country authors.

Some of the broad patterns emerging within this classificatory framework which are relevant for the discussion in the next section maybe noted.

First, apart from Hong Kong, most of our countries followed dirigiste policies to varying extents. However, in the so called post war golden age of the world economy, with its vast expansion of world trade, this mild dirigisme towards trade and industry did not do great damage to growth performance. It was during the more turbulent world economic environment .. 
post 1973 - that the effects of differing policy regimes on the efficiency of investment and thence their growth became manifest. Many of our countries suffered growth collapses (as judged by our country authors). In our land abundant group, 8 out of 10 (i.e., except Malaysia and Thailand) suffered a growth collapse. None of the labor abundant and only 3 (Jamaica, Peru and Madagascar) in the intermediate endowment group suffered a growth collapse.

The proximate cause of the growth collapses was an inflationary cum balance of payments crisis usually generated by unsustainable fiscal commitments. These fiscal crises had two major causes: (a) "big push" type development expenditures in Brazil, Peru, Nigeria, Ghana, Turkey and Madagascar, and (b) unsustainable social expenditures on income transfers and subsidies in Sri Lanka, Egypt, Jamaica, Mauritius, Uruguay and Costa Rica. Two striking patterns in these sources of fiscal imbalance were, first that most of the "big push" type fiscal imbalances were in land abundant countries. Second, except for Egypt, all the countries with unsustainable social expenditures were factional states.

Finally, in dealing with the crises which ensued, the response was found to be conditioned jointly by the country's polity and its underlying resource endowments. Thus by and large factional states (particularly of the democratic type) in relatively large land abundant countries, where it was economic to have large scale production, found it more difficult to change the policy regimes which had generated the crises, until economic ruin stared the polity in the face.

The classification according to differing initial resource endowments and the polity was useful in explaining these divergent policy regimes and outcomes. First, the labor abundant countries irrespective of their polity 
had the easiest development task. For them the standard policy prescription of the two factor Heckscher-Ohlin model of initially developing labor intensive industries and then moving up the ladder of comparative advantage is easy to follow. First, this policy leads to politically desirable factor price movements. With wages rising as capital is accumulated, there is unlikely to be political resistance from the bulk of the populace in factional states to policies which realize the country's comparative advantage. While all types of autonomous state will also find that even their predatory ends are better served by undertaking the development of their only resource -. the human -- on which their revenues and prosperity depend. The major task of government is to provide an adequate infrastructure to reduce the transactions costs of the relatively small scale organizational units which will predominate in the earlier stages of their development. Second, if the country is small (as were all three countries in our sample), the limited size of the domestic market makes reliance on foreign trade inevitable. Also there is unlikely to be vertical import substitution when the ubiquitous dirigisme leads to departures from free trade. This means that when a switch to freer trade is made there will not be lobbies preventing competitive imports of intermediate inputs. The political costs of rectifying past policy mistakes are likely to be lower than in the land abundant or intermediate group of countries. Third, their incremental comparative advantage is readily apparent to economic agents in both the public and private sectors. It is thus easier to pick "industrial winners" and the consequences of picking losers or policies which stimulate them more immediate .- as with Singapore's 111 -judged attempt to jump a few rungs on the ladder of comparative advantage through an artificial raising of wages. 
The comparative advantage of large land-abundant countries is also likely to be clearer than for the intermediate group, but more difficult to realize than for the labor abundant group of countries. This is for two reasons. First, with a higher supply price of labor than the labor abundant countries, due to their more favorable land-labor ratios, their incremental comparative advantage is likely to lie on the relatively capital intensive rungs of the ladder of comparative advantage. Public promotion may be required because of the ensuing lumpiness of investments, and the need to develop scarce skills and absorb complex imported technology. The dangers of "bureaucratic failure" endemic to such promotion may then lead to a failure to realize their economic potential. Second, if the rate of capital accumulation is not high enough, then with growing labor forces, their efficient development path could contain declining real wage segments. 5 If the polity is subject to factional democratic pressures, this "equilibrium" time path of real wages could lead to political pressures to resist the requisite real wage adjustments by turning inward. The polity could be at odds with the economy, with political cycles of economic repression (during factional political phases) followed by liberalization (during autonomous political periods). Third, given the political imperative of avoiding the "falling wage" segments of their development path, such countries have attempted "big push" development programs (to push their factor endowments towards the capital vortex in the Leamer triangle), often financed by foreign borrowing. This big push has often pushed them into a fiscal and debt crisis and thence a growth crisis.

Finally, the intermediate resource endowment group faces the most difficult development path. Their incremental comparative advantage is more opaque, so "mistakes" are not so easily recognized nor rectified, 
particularly by the public sector, which in the absence of any bankruptcy constraint resists the exit of inefficient firms. Secondly, this group was found to be more likely to face situations in which their polities were at odds with their comparative advantage.

One important conclusion arising from our country studies was the importance of stability in property rights (even more than their efficiency) in leading to a successful and sustainable growth performance. This does not mean that a clean (once for all and well defined) redistribution of property rights is ruled out. What is harmful is uncertainty about such redistribution. Furthermore, the definition of a right to property is in effect to claims on the income streams from the use of that property. Hence property rights are not altered only through asset redistribution, but also through changes in the implicit or explicit set of taxes and subsidies on factors of production and commodities, to which most public interventions are analytically equivalent, and which change the net income stream attached to "property". These taxes and subsidies must also include the changes in property rights that occur from the levying of the inflation tax. A stable fiscal and monetary constitution was thus also found to be an important part of a growth promoting economic framework.

\section{THE PROMOTION OF SOCIAL GAPABILITY}

The mainsprings of growth remain productivity, thrift and entrepreneurship. Their promotion is also synonymous with the creation of social capability. Our country studies provided ample evidence that this capability is best promoted through what can be called the classical liberal economic framework. Its clearest statement was in Mill's Principles, and its modern refurbishment is in Hayek's "Constitution of Liberty." Before delineating these principles, it is useful to consider why they have until 
fairly recently been rejected by most Third World countries in the post war period.

The clue to the widespread dirigiste impulse noted in Part II (also see Lal (1985)) lies in the economic nationalism which has been characteristic of nearly every Third World state. In this they echo the nationalist impulse of the absolutist monarchies after the Renaissance, which also sought to build cohesive nation states through dirigiste policies (see Heckscher (1955)). Their mercantilist system of controls and regulation, set up to pursue the objective of "nation building", has obvious resonances in the neo-mercantilist policies pursued by most Third World states. But these absolute monarchies found that after some initial success, far from building nations their dirigiste policies were becoming counterproductive, and leading to national disintegration. The consequences of their regulations and controls, particularly of internal trade and industry, were similar to those observed in many developing countries- corruption, rent seeking, tax evasion and the growth of illegal activities in growing underground economies. As has been observed for many developing countries (see Lal (1987)) and is confirmed by our country studies, one paradoxical dynamic effect of attempts to exercise political control over ever-increasing areas of economic life has often been that after a certain stage, there is a diminution of the government's effective areas of control -. an unMarxian withering away of the State - - as private agents find numerous ways of avoiding them. The most important sign of this for any state is loss of control over its fiscal affairs. With the expansion of politically determined entitlements as part of the mercantilist system of a politicized economy, the accompanying tax burden to finance them leads at some stage to generalized tax resistance. Faced with inelastic or declining revenues but 
burgeoning expenditure commitments incipient or actual fiscal deficits become chronic. It is to regain government control over increasingly ungovernable economies that economic liberalization was undertaken in the great Age of Reform in the 19th century. Paradoxically, as Heckscher notes the new economic liberalism (though short lived) achieved the goal sought by mercantilism:

Great power for the state, the perpetual and fruitless goal of mercantilist endeavour, was translated into fact in the 19 th century ... The result was attained primarily by limiting the functions of the state, which task laissez-faire carried through radically. The maladjustment between ends and means was one of the typical features of mercantilism, but it disappeared once the aims were considerably limited. Disobedience and arbitrariness, unpunished infringements of the law, smuggling and embezzlement flourish particularly under a very extensive state administration and in periods of continually changing ordinances and interferences with the course of economic life. It was because the regime de l'ordre bore this impress that disorder was one of its characteristic features.

(Heckscher, p. 325)

The same process seems to be occurring today in the neo-mercantilist states of all three worlds, which has led to a new worldwide Age of Reform in the 1980s.

What are the principles of economic liberalism, and how do they differ from those derived within the Arrow-Debreu market failure based view of public policy? The two most important are Gladstonian finance and sound money. ${ }^{6}$ The requirements of the latter are self evident, and broadly accepted today. The former, however, would be contested by proponents of contemporary optimal tax theory. The latter embodies two views about the economy whose precursor is J.S. Mill. The first is that questions of allocation can be separated from those concerning the distribution of income (see Mill, p. 3459-50), what Hayek has termed the "manna from heaven" presumption of contemporary distributivist theory (see Gray (1984)). The second is the neglect of the polity (see Barry), so that for purely 
technical reasons, in public economics the government is assumed to be composed of a committee of Platonic Guardians.

As our country studies have shown, and is apparent from the economic history of both western economies as well as of communist countries, the pre-Mill classical insight is still valid. A point which has been reiterated by the new institutional economics. As Bardhan (1989) notes:

one of the main pillars of Walrasian neo-classical economics - the separability of equity and efficiency -- breaks down when transactions costs and imperfect information are important; the terms and conditions of contracts in various transactions which directly affect the efficiency of resource allocation, now crucially depend on ownership structures and property relations. (p.1389)

The growth and productivity outcomes of particular institutional forms cannot be separated from their system of property rights, and the distribution of income streams flowing from them. The equity-efficiency tradeoff is a chimera.

Nor can the central assumption about the polity underlying optimal tax theory be supported by even casual empiricism. Thus two of the proponents of this theory for developing countries assume that :

the government has coherent, unified and largely benevolent objectives, captured in the social welfare function, and we search for ways in which the tools available to it can be used to improve the measure of welfare.

(Stern and Newberry (1987) p. 653).

As our country studies have shown, except for rare cases, most polities do not come even close to these assumptions about their character. Once a predatory or rent seeking polity is accepted as being common, the pattern of optimal taxes envisioned by Ramsey -- even from the viewpoint of a neutral outside observer - - is no longer desirable. In fact, this yields exactly the set of revenue maximizing taxes that a predatory state would choose to levy! (See Brennan-Buchanan (1980); Lee and Tollison (1988); Lal (1990).) 
An important difference in the neutrality of taxation as envisaged by Ramsey and under Gladstonian finance is that for the former it means reducing the deadweight cost of taxation, while for the later it refers to the generality or uniformity of the tax. As Harberger (1987) has noted (in a discussion which looks at various arguments for these two forms of neutrality) the main difference of these two approaches is their different philosophies of government, one of which corresponds to the classical liberal view, the other to the social engineering view. That the latter is really a form of neo-mercantilism can be readily seen from the fact that in this modern variant, the objective of economic policy is no longer the welfare of the state but the welfare of citizens as summarized in a social welfare function laid down by the state.

If we thus eschew the social engineering viewpoint underlying much technocratic policy advice, as being mercantilism in another garb, and accept that the most important way to promote social capability is to establish a policy framework that emphasizes economic freedom (misleadingly called laissez faire) this does not imply, as some seem to assume that the government should be "inert or indifferent". As Henderson (1986) has noted:

Liberalism's emphasis is a positive one. It is concerned with economic freedom, including the freedom of individuals and enterprises to enter industries or occupations, to choose their place of residence or operation within a country, and to decide their own products, processes and markets. There is nothing outdated about these principles nor do they operate against the weak. To the contrary, they enable opportunities to be opened up more widely, and thus operate against special privileges within an economic system ... In any case, liberalism is not to be identified with hostility to the state, nor with a doctrinaire presumption that governments have only a minor role in economic iife. On the contrary, the liberal view of the role of the state, both internal and external, is strongly positive. (p. 98)

For the Third World the essential tasks of governments from a liberal viewpoint are considerable. As Bauer summarized them: 
the tasks include the successful conduct of external affairs, notably the defense of the country, and also the preservation and encouragement of external communications and contacts; the maintenance of public security; the effective administration of the monetary and fiscal system; the promotion of a suitable institutional framework for the activities of individuals; and the provision of basic health and education services and of basic communications.

(Bauer (1984) p. 28)

That these tasks have so rarely been fulfilled by many Third World states, provides a measure of what still needs to be done to promote social capability from a liberal point of view. But how the different states we observe can be made to undertake these tasks, and not indulge in the predatoriness commonly found, remains an open question. For whatever the contemporary imperatives which may have forced many Third World states to embrace economic liberalism -. however reluctantly -. if their inherent character has not altered, they will be open to the siren voices of new forms of mercantilism in the future. How to tie a reluctant Ulysses to the mast, remains the most important unsettled question of political economy. 


\section{REFERENCES}

Aggarwal, R. (1983), "Price Distortions and Growth in Developing Countries," World Bank Staff Working Paper, No.575, Washington, DC: World Bank, 1983. Arrow, K.J., "The Economic Implications of Learning by Doing," Review of Economic Studies, 29 (1962).

Bardhan, P., "The New Institutional Economics and Development Theory: A

Brief Critical Assessment," World Development, 17 \#9 (1989).

Barro, R., "Economic Growth in a Cross Section of Countries,"

Quarterly Journal of Economics, CVI, \#2 (1991).

Barry, B., Sociologists. Economists and Democracy, Chicago. 1078.

Bauer, B., Reality and Rhetoric: Studies in the Economics of Development,

London: Weidenfeld and Nicholson, 1984.

Benhabib, J. and B. Jovanovic, "Externalities and Growth Accounting,"

American Economic Review, 81 \#1 (1991).

Brennan, G. and J.M.Buchanan, The Power to Tax, Cambridge, 1980.

Fisher, I., The Theory of Interest, New York, 1930.

Gray, J., Hayek on Liberty, Oxford: Blackwell, 1984.

Harberger, A.C., "Neutral Taxation," in Eatwell, et al. (eds.), The New

Palgrave, London: Macmillan, 1987.

Hayek, F., The Constitution of Liberty, London: Routledge, 1960.

Heckscher, H., Mercantilism, 2 vols, 2nd rev. edn., London: Allen and Unwin, 1955.

Henderson, P.D., Innocence and Design-The Influence of Economic Ideas on

Policy, Oxford: Blackwell, 1986.

Johnson, H.D., "Towards a Generalized Capital Accumulation Approach to Economic Development," in OECD, The Residual Factor and Economic Growth, 
Paris, 1964.

Kaldor, N., "A Model of Economic Growth," Economic Journal, 67 (1957).

Krueger, A.0., "Growth, Distortions and Patterns of Trade Among Many

Countries," Princeton Studies in International Finance, no.40, Princeton,

New Jersey, 1977.

La1, D., The Poverty of 'Development Economics', Cambridge, MA: Harvard University Press, 1985.

, "The Political Economy of Economic Liberalization," World Bank

Economic Review, 1 \#2 (1987).

, "The Political Economy of Industrialization in Primary Product

Exporting Economies: Some Cautionary Tales," in N.Islam (ed.), The

Balance Between Industry and Agriculture in Economic Development, vol. 5:

Factors Influencing Change, International Economic Association, London:

Macmillan, 1989.

, "Fighting Fiscal Privilege - Towards a Fiscal Constitution,"

paper no.7, London: Social Market Foundation, 1990.

and H. Myint, "The Political Economy of Poverty Equity and

Growth, " mimeo, London, 1991.

Lee, D.R. and R.D.Tollison, "Optimal Taxation in a Rent Seeking Environment,"

in C.K. Rowley, et al. (eds,), The Political Economy of Rent-Seeking,

Boston: Kluwer, 1988 .

Leamer, E., Sources of International Comparative Advantage, Cambridge, MA:

MIT, 1984.

, "Paths of Development in the Three Factor in Good General

Equilibrium Model, " Journal of Political Economy, 95 \#5 (1987).

Lucas, R.E., "On the Mechanics of Economic Development," Journal of Monetary

Economics, 94 (1988). 
Mill, J.S. (1970), Principles of Political Economy, ed. Donald Winch, London: Pelican, 1970 .

Murphy, K.M., A. Shleifer and R.Vishny (1991), "The Allocation of Talent: Implications for Growth" Quarterly Journal of Economics, CVI \#2 (1991).

Myint, H., "Organizational Dualism and Economic Development," Asian Development Review, 3 \#1 (1985).

Newberry, D. and N. Stern (eds.), The Theory of Taxation for Developing Countries, Oxford, 1987.

North, D., Structure and Change in Economic History, New York, 1981.

Romer, P. (1986), "Increasing Returns and Long Run Growth," Journal of Political Economy, 94 (1986). , "Crazy Explanations for the productivity slowdown," in S.

Fischer (ed.), NBER Macroeconomic Annual 1987, Cambridge, MA: MIT, 1987. , "Capital Accumulation in the Theory of Long Run Growth," in R.J.

Barro (ed.), Modern Business Cycle Theory, Cambridge, MA: Harvard University Press, 1989.

Scott, M. Fg., A New View of Economic Growth, Oxford: Clarendon Press, 1989.

Stern, N., "The Determinants of Growth", Economic Journal, 101 (June, 1991).

Williamson, O.E., "Transactions Costs Economics: The Governance of Contractual Relations," Journal of Law and Economics, 22 \#2 (1979). The Economic Institutions of Capitalism, NY: Free Press, 1985. 


\section{APPENDIX}

Consider the simple model of a free-trade world depicted by the Leamer Endowment Triangle in Figure A-1. Assume all goods are traded and produced with fixed coefficients. There are five manufactured goods produced by labor and capital, of increasing capital intensity whose input vectors are shown as $M_{1} \ldots M_{5}$ along the "labor-capital" edge of the triangle. There are two agricultural goods: $A_{1}$ produced only with labor and land, and $A_{2}$ which is more land intensive than $A_{1}$ and also uses all three factors of production. For a given set of commodity prices, the endowment triangle can then be divided into seven "regions of diversification" (by connecting the seven input vector points and the three axis coordinates). Countries with factor endowments in the same region of diversification will have the same factor prices and produce the same commodities with factor inputs given by the relevant vertices. Given commodity prices, relative factor intensities determine factor prices in each region. Now consider two illustrative development paths in this model. The first is that of a typical land and capital scarce but labor abundant country whose endowment point $E$ !A is on, or close to, the "labor-capital" axis. With capital accumulating faster than the growth of the labor force, assume the country which we label "labor abundant" moves up the ladder of comparative advantage with respect to manufactured goods, with rising capital intensity. Hence on this development path the wage rises and the rentals on capital and land fall. The second path is for a land abundant, but labor and capital scarce country whose endowment point $E_{1}$ lies in the region of diversification II, where it produces both the relatively labor intensive agricultural good $A_{1}$ and the land-cum-capital intensive good $A_{2}$. Consider one possible path of 
development with both capital and labor growing. Suppose the path of the economy's changing factor endowment is given by the dashed line from $E_{1}$. The economy will then move from Region I to VII to VI to IV. In this process it will begin to industrialize as soon as it moves into Region VI, but in the most capital-intensive manufacture. Over time it will move into regions which require specialization in increasingly more labor intensive goods. The factor price consequence of this development path will be a falling wage rate, and from the time the economy moves into Region VII, rising rental rates on capital and land. The functional distributional (and ipso facto political) implications of the required path of wages on this stylized land-abundant open economy's development path (with a falling wage) would be very different from those of the stylized labor abundant case (with rising wages) which are also produced by the standard two-factor models. But note that, even though the wage might be falling in the course of the land abundant country's development (for some time), it will still be higher than for the labor intensive country until both wage paths converge on the region of specialization in Region IV. ${ }^{1}$ The 3 factor model of trade and growth provides us with the requisite richness of efficient development paths. It emphasizes the importance of initial resource endowments, and also through the factor price implication of changing factor proportions provides a direct link from the economy to the polity.

\footnotetext{
IIt might seem paradoxical that, while the economy's capital-labor ratio is rising, it is falling in manufacturing. But remember that the rate of growth of labor for the economy is not the same as in manufacturing. Then, it is possible for the agricultural labor force to grow more slowly (because of fixed land) than for the economy as a whole, thereby allowing and requiring the labor force in the manufacturing sector to grow more rapidly than for the economy as a whole. Thus a rising capital labor ratio for the economy as a whole can be associated with a falling capital labor ratio in manufacturing. of course, there will be some rate of capital growth at which the capital labor ratio for manufacturing will also be rising along with that for the economy as a whole, and this paradoxical development path would not occur.
} 
FIGURE A-1

Qutputs Produced

Region I

Region II

Region III

Region IV

Region V

Region VI

Region VII
$A_{1}, M_{1}$

$A_{1}, A_{2}$

$A_{1}, M_{1}, M_{2}$

$A_{1}, A_{2}, M_{3}, M_{4}$

$A_{1}, A_{2}, M_{3}, M_{4}$

$A_{2}, M_{4}, M_{5}$

$A_{2}, M_{3}$

\section{Wage Rate}

$\mathrm{W}_{1}$

$\mathrm{w}_{2}>\mathrm{w}_{1}$

$\mathrm{w}_{3}>\mathrm{w}_{1}$

$w_{4}>w_{3}$

$W_{5}>W_{4}$

$w_{6}>w_{5}$

$w_{7}>w_{6}>w_{2}$ 
NOTES

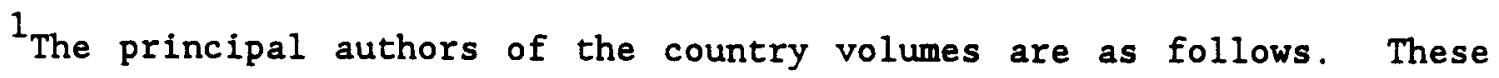
volumes are currently in press with the publishers' names given in brackets):

1. Malawi and Madagascar by Frederic Pryor, Oxford, 1991.

2. Egypt and Turkey by Bent Hansen, Oxford, (in press).

3. Sri Lanka and Malaysia by Henry Bruton, Oxford, (in press).

4. Indonesia and Nigeria by D. Bevan, P. Collier and J. Gunning, Oxford, (in press).

5. Thailand and Ghana by O.A. Meesook, D. Rimmer and G. Edgren, Pergamon, (in press).

6. Brazil \& Mexico by A. Maddison and Associates, Oxford, (in press).

7. Costa Rica and Uruguay by S. Rottenberg, C. Gonzales-Vega and E. Favaro, Oxford (in press).

8. Colombia and Peru by A. Urdinola, M. Carrizossa \& R. Webb, (mimeo, World Bank, Latin American Dept., 1990).

9. Five Small Economies (Hong Kong, Singapore, Malta, Jamaica, Mauritius) by R. Findlay and S. Wellisz, Oxford (in press).

In addition, a collection of essays has been produced:

10. G. Pscaharopoulous (ed): Essays on Poverty, Equity and Growth.

Finally, the synthesis volume by Lal and Myint (1991) is currently being prepared for publication. This paper is based in large part on this draft synthesis volume.

2 These costs of doing business are part of transactions costs. On their importance in the evolution of institutions as well as determining the historical evolution of Western economies, see Williamson $(1979,1985)$ and 
North (1981).

${ }^{3}$ See the debate between Scott, Eisner and Bradford on the proper accounting procedures for depreciation in the September 1990 issue of the Journal of Economic Literature.

${ }^{4}$ The term "predatory" reflects the symbiotic relationship between the State and its citizens, as in the predator-prey models of the natural world. Though self-seeking, a predator is concerned to some extent with the welfare of the prey, which provides it with its food supply!

${ }^{5}$ of our land abundant countries, except for the top performers (Thailand and Malaysia), all the rest had " $U$ " or inverted "U" shaped time paths of real wages.

${ }^{6}$ Schumpter (1954) lists three basic principles of Dladstonian finance: (1) Retrenchment means that "the most important thing is to remove fiscal obstructions to private activity. And for this, it is necessary to keep public expenditure low." (2) Neutrality implies "raising the revenue that would still have to be raised in such a way as to deflect economic behavior as little as possible from what it would have been in the absence of all taxation." (3) Balance refers to the principle of the balanced budge, or rather, since debt is to be reduced, "the principle that Robert Low ... embodied in his definition of a minister of finance: "an animal that ought to have a surplus." (p. 403-5) 
TABLE 1

REAL GDP PER CAPTITA IN 1980 INTERNATIOMAL PRICES

\begin{tabular}{|c|c|c|c|c|c|c|}
\hline & & 1950 & 1955 & 1960 & 1980 & $\begin{array}{c}\text { GROWTH } \\
\text { RATE } \\
1960-85 \\
\end{array}$ \\
\hline Malaw1 & MW & & 212 & 237 & 387 & 2.0 \\
\hline Indonesia & IND & & & 494 & 1255 & 3.8 \\
\hline Egypt & EG & 427 & 433 & 496 & 1188 & 3.6 \\
\hline Ghana & GH & & 511 & 534 & 349 & -1.7 \\
\hline Nigeria & NIG & 478 & 543 & 552 & 581 & 0.2 \\
\hline Madagascar & MDGR & & & 659 & 497 & -1.1 \\
\hline Thailand & $\mathrm{TH}$ & 638 & 516 & 688 & 1900 & 4.1 \\
\hline Sri Lanka & SL & 787 & 868 & 974 & 1539 & 1.8 \\
\hline Brazil & BZ & & 832 & 991 & 3282 & 4.9 \\
\hline Maritius & $\mathbf{M R}$ & 1253 & 1145 & 1012 & 1869 & 2.5 \\
\hline Malaysia & MLY & & 1006 & 1103 & 3415 & 4.6 \\
\hline Turkey & TK & 822 & 1132 & 1255 & 2533 & 2.8 \\
\hline Malta & MLA & & 1087 & 1282 & 5319 & 5.9 \\
\hline Columbia & $\mathrm{COL}$ & 1188 & 1376 & 1344 & 2599 & 2.7 \\
\hline Jamaica & JAM & & 1117 & 1472 & 1725 & 0.6 \\
\hline Singapore & SING & & & 1528 & 9834 & 7.7 \\
\hline Costa Rica & CR & 1175 & 1541 & 1663 & 2650 & 1.9 \\
\hline Peru & PR & 1235 & 1501 & 1721 & 2114 & 0.8 \\
\hline Hong Kong & HK & & & 1737 & 9093 & 6.3 \\
\hline Mexico & $\mathbf{M X}$ & 1652 & 1905 & 2157 & 3985 & 2.5 \\
\hline Uruguay & UR & 2864 & 3523 & 3271 & 3462 & 0.2 \\
\hline
\end{tabular}

NB ' 1960 ' Indonesian figure is for 1962

Source: "A New Set of International Comparisons of Real Product and Prices for 130 Countries, 1950-85," Robert Summers and Alan Heston, in The Review of Income and Wealth. March 1988 , Series 34 , No. 1 
Endogenous Variables: INV EXPGRT

Instruments: C LAB EXPCHG DUMTR GOVC PRIMED LITAD AGRLAB URBP

(A) Dependent Variable: GRTH; No. of Observations = 21

\begin{tabular}{|c|c|c|c|c|c|c|c|c|c|}
\hline & C & INV & $\mathrm{LAB}$ & EXPGRT & EXPCHG & GOVC & PRIMED & LITAD & Rsq \\
\hline R.I & & $\begin{array}{l}0.13^{\star \star} \\
(2.31)\end{array}$ & $\begin{array}{c}0.85^{\star} \\
(1.93)\end{array}$ & & & & & & 0.94 \\
\hline R.II & & $\begin{array}{c}0.11^{\star \star} \\
(2.44) \\
\end{array}$ & $\begin{array}{r}0.67^{\star} \\
(2.00) \\
\end{array}$ & $\begin{array}{l}0.22^{\star \star} \\
(2.39) \\
\end{array}$ & & & & & 0.97 \\
\hline R.III & & $\begin{array}{c}0.06 \\
(0.75) \\
\end{array}$ & $\begin{array}{c}1.31^{\star \star} \\
(2.46) \\
\end{array}$ & & $\begin{array}{c}0.05 \\
(1.51) \\
\end{array}$ & & & & 0.94 \\
\hline R.IV & $\begin{array}{r}-0.02 \\
(1.7) \\
\end{array}$ & $\begin{array}{l}0.23^{\star \star \star} \\
(2.94) \\
\end{array}$ & $\begin{array}{c}0.97^{\star *} \\
(2.35) \\
\end{array}$ & & & & & & 0.67 \\
\hline R.V & $\begin{array}{l}-0.02 \\
(1.26) \\
\end{array}$ & $\begin{array}{l}0.18^{\star \star} \\
(2.5) \\
\end{array}$ & $\begin{array}{l}0.79^{\star \star} \\
(2.22) \\
\end{array}$ & $\begin{array}{r}0.17 \\
(1.65) \\
\end{array}$ & & & & & 0.79 \\
\hline R.VI & $\begin{array}{l}-0.02 \\
(0.82) \\
\end{array}$ & $\begin{array}{c}0.15 \\
(1.12) \\
\end{array}$ & $\begin{array}{l}1.84^{\star \star} \\
(2.23) \\
\end{array}$ & & $\begin{array}{c}0.03 \\
(0.68) \\
\end{array}$ & & & & 0.66 \\
\hline R.VII & $\begin{array}{l}-0.06 \\
(0.75) \\
\end{array}$ & $\begin{array}{c}0.20^{\star} \\
(2.53) \\
\end{array}$ & $\begin{array}{c}0.68 \\
(1.72) \\
\end{array}$ & $\begin{array}{c}0.15 \\
(1.35) \\
\end{array}$ & & $\begin{array}{l}-0.05 \\
(0.75) \\
\end{array}$ & & & 0.79 \\
\hline R.VIII & $\begin{array}{c}-0.01 \\
(0.63) \\
\end{array}$ & $\begin{array}{c}0.18^{\star} \\
(1.83) \\
\end{array}$ & $\begin{array}{r}0.76 \\
(1.6) \\
\end{array}$ & $\begin{array}{c}0.14 \\
(1.26) \\
\end{array}$ & & $\begin{array}{l}-0.05 \\
(0.6) \\
\end{array}$ & $\begin{array}{r}0.005 \\
(0.34) \\
\end{array}$ & & 0.79 \\
\hline R. IX & $\begin{array}{r}-0.005 \\
(0.29)\end{array}$ & $\begin{array}{c}0.22^{\star *} \\
(2.44)\end{array}$ & $\begin{array}{c}0.60 \\
(1.38)\end{array}$ & $\begin{array}{c}0.15 \\
(1.33)\end{array}$ & & $\begin{array}{l}-0.07 \\
(0.85)\end{array}$ & & $\begin{array}{r}-0.007 \\
(0.53) \\
\end{array}$ & 0.79 \\
\hline
\end{tabular}

Notes: $\quad \begin{aligned} & * * * \text { - significant at } 18 \\ & \\ & * * \text { - significant at } 2.58 \\ & * \text { - significant at } 58\end{aligned}$

GRTH - annual GDP growth rated 1950-85 (country studies)

INV - average share of investment in GDP 1950-1985

LAB - labor force growth rates 1960-85

GOVC - Govt. consumption as share of GDP, average 1965-85

EXPGRT - growth rate of exports 1960-85

EXPCHG - change in ratio of exports to GDP, 1985 and 1960

DUMTR - trade regime dumny (1-outward, 0 -inward oriented)

PRIMED - Percentage age group in primary education 1965

LITAD - Adult literacy rate in 1960

AGRLAB - percentage of labor force in agriculture 1965

URBP - urban population as percentage of total, 1965. 
TABLE 2

(continued)

GROWTH REGRESSIONS: TSLS

(B) Dependent Variable: GRTK

No. of Observations -21

\begin{tabular}{|c|c|c|c|c|c|c|c|c|c|}
\hline & C & INV & $\mathbf{L A B}$ & EXPGRT & EXPCHG & GOVC & PRIKLD & LITAD & Rsq \\
\hline R. I & & $\begin{array}{l}0.16^{\star \star} \\
(2.29)\end{array}$ & $\begin{array}{c}0.70 \\
(1.29) \\
\end{array}$ & & & & & & 0.92 \\
\hline R. II & & $\begin{array}{l}0.13^{\star \star} \\
(2.36)\end{array}$ & $\begin{array}{c}0.43 \\
(1.08) \\
\end{array}$ & $\begin{array}{l}0.32^{\star \star \star} \\
(2.97)\end{array}$ & & & & & 0.96 \\
\hline R.III & & $\begin{array}{c}0.08 \\
(0.78) \\
\end{array}$ & $\begin{array}{c}1.22^{\star} \\
(1.83)\end{array}$ & & $\begin{array}{c}0.05 \\
(1.37) \\
\end{array}$ & & & & 0.92 \\
\hline R.IV & $\begin{array}{l}-0.04^{\star \star} \\
(2.52)\end{array}$ & $\begin{array}{l}0.33^{\star \star \star} \\
(3.57)\end{array}$ & $\begin{array}{c}0.91^{\star} \\
(1.86)\end{array}$ & & & & & & 0.68 \\
\hline R.V & $\begin{array}{l}-0.03^{\star \star} \\
(2.2)\end{array}$ & $\begin{array}{l}0.26^{\star \star \star \star} \\
(3.21)\end{array}$ & $\begin{array}{c}0.66 \\
(1.64) \\
\end{array}$ & $\begin{array}{c}0.22^{\star} \\
(1.91) \\
\end{array}$ & & & & & 0.81 \\
\hline R.VI & $\begin{array}{l}-0.04^{*} \\
(1.91)\end{array}$ & $\begin{array}{c}0.34^{*} \\
(2.08) \\
\end{array}$ & $\begin{array}{c}0.88 \\
(1.40) \\
\end{array}$ & & $\begin{array}{r}-0.003 \\
(0.07)\end{array}$ & & & & 0.67 \\
\hline R.VII & $\begin{array}{l}-0.03 \\
(1.51) \\
\end{array}$ & $\begin{array}{l}0.26^{\star \star} \\
(2.32) \\
\end{array}$ & $\begin{array}{c}0.66 \\
(1.20) \\
\end{array}$ & $\begin{array}{c}0.21 \\
(1.63) \\
\end{array}$ & & $\begin{array}{l}-0.03 \\
(0.30) \\
\end{array}$ & & & 0.81 \\
\hline R.VIII & $\begin{array}{l}-0.03 \\
(1.33) \\
\end{array}$ & $\begin{array}{l}0.27^{\star \star} \\
(3.00)\end{array}$ & $\begin{array}{c}0.61 \\
(1.35) \\
\end{array}$ & $\begin{array}{c}0.21 \\
(1.71)\end{array}$ & & $\begin{array}{l}-0.02 \\
(0.10) \\
\end{array}$ & $\begin{array}{r}0.003 \\
(0.16) \\
\end{array}$ & & 0.81 \\
\hline R. IX & $\begin{array}{l}-0.02 \\
(0.99)\end{array}$ & $\begin{array}{l}0.31^{\star \star \star} \\
(2.99)\end{array}$ & $\begin{array}{c}0.46 \\
(0.91)\end{array}$ & $\begin{array}{c}0.22 \\
(1.66)\end{array}$ & & $\begin{array}{l}-0.05 \\
(0.55)\end{array}$ & & $\begin{array}{l}-0.01 \\
(0.91)\end{array}$ & 0.80 \\
\hline
\end{tabular}

Notes: Significance levels as in previous note. Figures in brackets are $t$ ratios. GRTK - annual growth rates of GDP Kravis dollars from Table 4.1

The other variables are as in previous footnote.

All the regressions in this table have been estimated by the GIVE procedure in the statistical package ECOS.

Page - 2- 
TABLE 3

DETERYINANTS OF GROWTH

(A) Growth of GDP (g), Investment Rate $(S)$, Growth of Labor Force $\left(G_{L}\right)$, Share of Wages $(\lambda)$ and Average Rates of Return to Investment ( )

\begin{tabular}{|c|c|c|c|c|c|}
\hline COUNTRY & 8 & $\mathbf{s}$ & $G_{L}$ & $\lambda$ & \\
\hline \multicolumn{6}{|c|}{ A. LABOR ABUNDANT } \\
\hline HONG KONG & 8.9 & 26.1 & 3.63 & na & na \\
\hline SINGAPORE & 8.3 & 34.0 & 3.86 & na & na \\
\hline MALTA & 5.6 & 26.1 & 1.35 & na & na \\
\hline \multicolumn{6}{|c|}{ B. LAND ABUNDANT } \\
\hline MALAYSIA & 6.9 & 23.0 & 3.39 & na & na \\
\hline THAILAND & 6.7 & 22.9 & 3.09 & 52.0 & 22.2 \\
\hline BRAZIL & 6.6 & 21.4 & 3.25 & 64.7 & 21.0 \\
\hline MEXICO & 5.7 & 18.2 & 3.55 & 64.7 & 18.7 \\
\hline TURKEY & 5.6 & 18.9 & 1.8 & 57.0 & 24.0 \\
\hline COSTA RICA & 5.0 & 22.0 & 3.65 & 58.5 & 13.0 \\
\hline COLOMBIA & 4.7 & 19.0 & 2.49 & 53.0 & 17.8 \\
\hline NIGERIA & 3.7 & 16.6 & 2.93 & 52.0 & 13.1 \\
\hline GHANA & 1.3 & 11.7 & 2.58 & $>100.0$ & -10.9 \\
\hline URUGUAY & 1.1 & 12.9 & 0.66 & 34.7 & 6.8 \\
\hline \multicolumn{6}{|c|}{ C. INTERMEDIATE } \\
\hline EGYPT & 5.4 & 19.4 & 2.29 & 43.4 & 22.7 \\
\hline INDONESIA & 5.3 & 15.2 & 2.62 & na & na \\
\hline SRI LANKA & 4.7 & 17.2 & 2.31 & 69.0 & 18.1 \\
\hline MALAWI & 4.3 & 23.4 & 2.51 & 50.1 & 13.0 \\
\hline PERU & 4.1 & 19.1 & 2.93 & na & na \\
\hline JAMAICA & 3.3 & 22.1 & 1.97 & na & na \\
\hline MAURITIUS & 2.9 & 22.3 & 2.60 & na & na \\
\hline MADAGASCAR & 2.0 & 14.3 & 1.79 & na & na \\
\hline
\end{tabular}

Note: $\mathbf{g}$ - growth rate of GDP (1950-85) from World Tables and country study

s -

$\lambda$ - share of wages. From country stidies and Anderson (1990). For Sri Lanka from Lal (1979).

- estimated from $=(g-\lambda G L / s$. 
TABIE 4

GROWTH AND TYPE OF POLITY

\begin{tabular}{|c|c|c|c|c|c|c|c|}
\hline \multirow{2}{*}{\multicolumn{2}{|c|}{ Region }} & \multirow{3}{*}{$\frac{\begin{array}{c}\text { Growth } \\
\text { Rate }\end{array}}{8.9}$} & \multicolumn{3}{|c|}{ Autonomous } & \multicolumn{2}{|c|}{ Factional } \\
\hline & & & \multirow{2}{*}{$\frac{\text { Plat }}{x}$} & \multicolumn{2}{|c|}{$\begin{array}{l}\text { Predatory } \\
\text { Author Buce }\end{array}$} & 0118 & Dem \\
\hline As & Hong Kong & & & & & & \\
\hline As & Singapore & 8.3 & $\mathbf{x}$ & & & & \\
\hline As & Malaysia & 6.9 & & & & & $\mathrm{x}$ \\
\hline As & Thailand & 6.7 & & $\mathrm{x}$ & & & \\
\hline LA & Brazil & 6.6 & & $\mathbf{x}$ & & & \\
\hline LA & Mexico & 5.7 & & & $\mathbf{x}$ & & \\
\hline $\mathbf{M E}$ & Malta & 5.6 & $\mathbf{x}$ & & & & \\
\hline $\mathbf{M E}$ & Turkey & 5.6 & $\mathbf{x}$ & & & & \\
\hline ME & Egypt & 5.4 & & $\mathrm{x}$ & & & \\
\hline As & Indonesia & 5.3 & & $\mathbf{x}$ & & & \\
\hline LA & Costa Rica & 5.0 & & & & & $\mathrm{x}$ \\
\hline LA & Columbia & 4.7 & & & & $\mathrm{x}$ & \\
\hline As & Sri Lanka & 4.7 & & & & & $\mathbf{x}$ \\
\hline Af & Malawi & 4.3 & $x$ & & & & \\
\hline LA & Peru & 4.1 & & & & $x$ & \\
\hline Af & Nigeria & 3.7 & & & & & $\mathbf{x}$ \\
\hline LA & Jamaica & 3.3 & & & & & $x$ \\
\hline As & Mauritius & 2.9 & & & & & $x$ \\
\hline Af & Madagascar & 2.0 & & & & $x$ & \\
\hline Af & Ghana & 1.3 & & $\mathbf{x}$ & & & \\
\hline LA & Uruguay & 1.1 & & & & & $\mathbf{x}$ \\
\hline
\end{tabular}

Ranked in terms of growth performance 